\title{
The Constitution of Liberal Order at the Troubled Beginnings of the Modern State
}

\author{
ROBERT W. GoRdon*
}

Among the many pleasures this symposium on and for Owen Fiss has given me is the opportunity to read over again, this time very carefully, his remarkable history of the Fuller Court, Troubled Beginnings of the Modern State, 1888-1910. ${ }^{1}$ This book is not as well-known as it should be. It is one of the most important of a series of recent reassessments of the high "classical" period of American public law. ${ }^{2}$ The Fuller Court decided, among others cases, Lochner, ${ }^{3}$ Plessy, ${ }^{4}$ In re Debs, ${ }^{5}$ Danbury Hatters, ${ }^{6}$ Adair ${ }^{7}$ E.C. Knight $^{8}$ and the Insular ${ }^{9}$ and Chinese Exclusion cases, ${ }^{10}$ a notable list of "negative examples," as Fiss calls them. ${ }^{11}$ His job, as he saw it, was to historicize those cases, to

* Chancellor Kent Professor of Law and Legal History, Yale University. Prepared for symposium in honor of Owen Fiss, University of Miami School of Law, March 21-22, 2003. Thanks to Jules Coleman, Stephen Diamond, Owen Fiss, Alvin Klevorick, Jonathan Simon and Peter Schuck for helpful comments.

1. Owen M. Fiss, Troubled Beginnings of the Modern State, 1888-1910 (1993).

2. See, e.g., Howard Gillman, The Constitution Besieged: The Rise and Demise of Lochner Era Police Powers Jurisprudence (1993); Morton J. Horwttz, The Transformation of American Law, 1780-1860 (1977); Edward A. Purcell JR., Litigation and INequality (1992); Willliam M. Wiecek, The Lost World of Classical Legal Thought: Law and IDEOLOGY IN AMERICA, 1886-1937 (1998); Michael Les Benedict, Laissez-Faire and Liberty: A Reevaluation of the Meaning and Origins of Laissez-Faire Constitutionalism, 3 LAw \& HIST. Rev. 293 (1985); Herbert Hovenkamp, The Political Economy of Substantive Due Process, 40 Stan. L. Rev. 379 (1988); Duncan Kennedy, Towards an Historical Understanding of Legal Consciousness: The Case of Classical Legal Thought in America, 1850-1940, 3 Res. IN LAw \& Soc. Theory 3 (1980); Charles W. McCurdy, Justice Field and the Jurisprudence of Government-Business Relations: Some Parameters of Laissez-Faire Constitutionalism, 18631897, 61 J. Aм. Hist. 970 (1975); Stephen A. Siegel, Lochner Era Jurisprudence and the American Constitutional Tradition, 70 N.C. L. Rev. 1 (1991); Melvin I. Urofsky, State Courts and Protective Legislation During the Progressive Era: A Reevaluation, 72 J. AM. Hist. 63 (1985).

3. Lochner v. New York, 198 U.S. 45 (1905).

4. Plessy v. Ferguson, 163 U.S. 537 (1896).

5. In re Debs, 158 U.S. 564 (1895).

6. Loewe v. Lawlor, 208 U.S. 274 (1908) (the Danbury Hatters Case).

7. Adair v. United States, 208 U.S. 161 (1908).

8. United States v. E.C. Knight, 156 U.S. 1 (1895).

9. Downes v. Bidwell, 182 U.S. 244 (1901); Hawaii v. Mankichi, 190 U.S. 197 (1903); Dorr v. United States, 195 U.S. 138 (1904); Balzac v. Porto Rico, 258 U.S. 298 (1922).

10. Chae Chan Ping v. United States, 130 U.S. 581 (1889) (The Chinese Exclusion Case); Chew Heong v. United States, 112 U.S. 536 (1884); United States v. Jung Ah Lung, 124 U.S. 621 (1888); Fong Yue Ting v. United States, Wong Quan v. United States; Fong Yue Ting v. United States, 149 U.S. 698 (1893).

11. Fiss, supra note 1. 
reconstruct as faithfully as scholarly care makes possible and, as sympathetically as the generous spirit and aroused conscience of an Owen Fiss could allow, the mentality of the judges who decided and the lawyers who argued them, and the age that found their reasoning plausible. The result is a Baryshnikov of a book - lithe, muscular and elegant, with moments of acrobatic virtuosity. Only an exceptionally good historian could have maneuvered his mind so closely alongside the categories and assumptions of the opinions; only an exceptionally good lawyer could have traced their reasoning with such analytic precision.

There are many riches in this book; but my main interest on this occasion is in its largest generalizations, its account of the social vision or conceptual scheme that underlies the cases - its account of a particular version of "liberty" as the fundamental commitment of the Fuller Court. This was, Fiss tells us, a commitment not to anarchy or license, to allowing people to do anything they like, but rather to "ordered liberty" in the "social contract" tradition. This tradition distinguishes the "social" from the "political"; that is, the private from the public. The "social" realm includes "all those activities of individuals that are connected to their happiness or well-being." The "political" sphere is the state.

The implication is that even without a state, people can achieve a measure of happiness through the pursuit of self-interest and the formation of exchange relationships. As a result, the market, growing from the social realm, is treated as the basic ordering mechanism of society and the state as a derivative or supplemental institution. The state is an artificial creation, not part of the social order nor responsible for it. The state is an instrument, created to serve certain discrete ends that exist prior to and independent of it. Its duty is to facilitate exchange in the social realm by protecting property rights, among others, and to bring to an end those activities - for example, outbursts of violence or fraud - that prevent individuals from engaging in exchange or otherwise fully realizing their own ends. ${ }^{12}$

The danger was that the "apparatus of the state might be seized by groups who wished to use it for purposes of altering or transforming the social order, for example by interfering with exchange relationships or by taking the wealth of some and giving it to others."13 Against this danger stood the idea of the Constitution as embodying the basic terms of the social contract limiting state authority, enforced by judges. Lochner v. New York, ${ }^{14}$ Adair v. United States, ${ }^{15}$ and, in a somewhat indirect

12. Fiss, supra note 1 at 47.

13. Id. at 48 .

14. 198 U.S. 45 (1905).

15. 208 U.S. 161 (1908). 
fashion, Pollock v. Farmers' Loan \& Trust Co. (The Income Tax Case) ${ }^{16}$ are the paradigmatic illustrations. Lochner is a decision about "constitutive authority," which Fiss distinguishes from "organic authority," authority in the "social" sphere, such as a parent holds over a child. "[C]onstitutive authority does not arise naturally nor is it intrinsic to some ongoing relationship. Like that of a club or voluntary association, it is artificially created to serve discrete ends." 17 As such, it is bound not only by general external restraints such as principles of morality, but also by internal restraints, arising from "the very reasons for which that authority is created . ... Such limits require that every exercise of [constitutive authority] be justified in terms of the ends for which that power was created." 18 The exercise of state police power, for instance, was viewed as legitimately serving four discrete ends - health, safety, welfare, and morals - and was constitutionally required to economize on, or as we would now say, "narrowly tailor," its means to those ends.

Sometimes Fiss frames the "liberty" protected by enforcing constitutional limits on constitutive authority simply as "the space or area left to the individual after the reasons for the creation of state power were exhausted. Liberty of contract was what remained to the individual after the state reached the outer bounds of its authority." 19 But then he realizes that this account of liberty as residual space is not quite adequate, to the extent it implies that the legal system is indifferent to what people do in that space, that the courts shrug their shoulders and say, "Whatever turns you on." On the contrary, the courts meant to valorize, indeed to preserve as a semi-sacred sphere of action, exercises of liberty with a particular content, "the freedom of the parties [in the social sphere] to bargain - a freedom that was seen as the central dynamic of the market and of the social contract tradition"20 - that is, entrepreneurial liberty, the rights to contract, choose one's calling, manage and invest one's property, and trade one's property and labor on such terms as one could negotiate.

Contractarianism was devoted to liberty as the end of all social arrangements and identified the state both as a necessary tool to secure the enjoyment of liberty and the principal threat to it. Individuals, it was assumed, would justly order their economic and social relationships through exchange; the state would be needed to enforce those bargains and to create the proper conditions of exchange. Legislative majorities might sometimes seek to assign the state more

16. 157 U.S. 429 (1895).

17. FISs, supra note 1 , at 158 .

18. Id. at 159 .

19. Id. at 159; see also id. at 357.

20. Id. at 164 . 
ambitious undertakings, but under the terms of the social contract, fixed once and for all, that option was not available. ${ }^{21}$

I note in passing that this new formulation of the contractarian position gives a somewhat larger role than Fiss's first version to the state as a "necessary tool" in the operations of the social sphere - the "artificial" has suddenly been inserted into the very constitution of the "natural" - and I will come back to this point. But for now, let me affirm that Fiss thoroughly makes the case for the Fuller Court's commitment to the primacy of liberty. It is all the more striking, therefore, that his book should largely be a record of what, from a modern libertarian's perspective, looks like a cornucopia of illiberal and often starkly repressive actions, most of them blessed, and some even initiated, by the same judicial guardians of liberty. And these actions of the Supreme Court that Fiss records are only fragments of a far-flung archipelago of illiberal state policies around the turn of the century, nearly all of them approved, cheered on, or at least let pass in silence, by orthodox classical liberal courts.

In re Debs, ${ }^{22}$ to start with, is of course one of thousands of cases in which courts wielded injunctions to restrain the liberty, as labor saw it, of trade unions to act collectively through strikes, pickets and boycotts to improve their bargaining position to negotiate wages and working conditions. The Court also generally allowed, and indeed cheered on, legislation violating the core premises of entrepreneurial liberty and equal treatment, where the class "protected" by statutory exclusion from the professions and other occupations and limits on hours of work was women rather than men. ${ }^{23}$ In the Insular Cases, the Court ratified (albeit over vigorous dissents) the exclusion of inhabitants of territories from Constitutional protections of their liberties; ${ }^{24}$ in the Chinese Exclusion Cases ${ }^{25}$ it did the same for Chinese immigrants, allowing the government the unconstrained discretion to expel them at will. ${ }^{26}$ In Plessy $v$. Ferguson, ${ }^{27}$ the Court validated Jim Crow's statutes mandating the expulsion of blacks from spaces in public accommodations reserved for whites, thus enforcing the racial caste hierarchies of the South. ${ }^{28}$ In Mugler v. Kansas (decided just before Fiss's period begins), ${ }^{29}$ the Court

21. Id.

22. 158 U.S. 564 (1895).

23. Fiss, supra note 1 , at $176-79$.

24. Id. at 225-26.

25. 130 U.S. 581 (1889).

26. Id. at $298-311$.

27. 163 U.S. 537 (1896).

28. FIss, supra note 1 , at $352-56$.

29. 123 U.S. 623 (1887). 
upheld the authority of states to seize the property of distillers and destroy their businesses, without compensation. ${ }^{30}$ In Turner $v$. Williams,${ }^{31}$ the Court allowed the government to deport an alien for holding the views of a philosophical anarchist ${ }^{32}$ and in Patterson v. Colorado ${ }^{33}$ the Court allowed state judges to punish for criminal contempt a publisher who had criticized their court. ${ }^{34}$ In both cases the Court casually brushed aside the defendants' First Amendment claims. In the last case discussed in Fiss's book, Hodges v. United States, ${ }^{35}$ the Court is seen declaring the federal government powerless to protect black workers seeking to exercise their fundamental liberty to contract for their labor - against violent white gangs. ${ }^{36}$

Fiss sees some of these cases as consistent with the Court's commitment to contractarian liberty, and others more like a betrayal. Of the Insular Cases, ${ }^{37}$ he says, "Here all sense of [contractual] limits is gone and the relation of state to subject appears more organic than contractual." 38 But he is careful to demonstrate how, in the Court's mind, all these decisions could have been rationalized to fit into the overall scheme of contractual liberty.

The nationwide Pullman strike of railroad workers led by Eugene Debs represented to the judges a direct coercive interference with the property of employers, their liberty to hire and fire, and with the liberty of non-union workers to contract for their work. But even more basically, it threatened the basic conditions of public peace and order upon which all social relations, including market relations, were built so much so that the federal courts felt an imperative of general order-preservation in the public welfare to bypass (potentially nullifying) jury trials and to issue injunctions. Similarly, Turner, ${ }^{39}$ which validated exclusion of anarchists, was broadly justified as an exercise of governmental power to suppress speech with a "bad tendency," however remote the risk of some damage to public order.

The cases dealing with state regulation of women, aliens and territorials, on the other hand, involved disenfranchised groups, not "members of the constitutional community" and therefore not entitled to

30. 123 U.S. 623 (1887).

31. 194 U.S. 279 (1904).

32. Fiss, supra note 1, at 331-39.

33. 205 U.S. 454 (1907).

34. Fiss, supra note 1 , at $340-48$.

35. 203 U.S. 1 (1906).

36. Id. at $379-85$.

37. Downes v. Bidwell, 182 U.S. 244 (1901); Hawaii v. Mankichi, 190 U.S. 197 (1903); Dorr

v. United States, 195 U.S. 138 (1904); Balzac v. Porto Rico, 258 U.S. 298 (1922).

38. Id. at 295.

39. Turner v. Williams, 194 U.S. 279 (1904). 
liberty and equal treatment as full sui juris citizens. ${ }^{40}$ Disenfranchisement was not only "a reason for being more tolerant of exercises of state power purportedly on behalf of this group, allowing the state to pursue ends otherwise denied it," ${ }^{41}$ but also a justification for exclusionary or oppressive treatment. Women and children in particular were wards of the state and thus the proper subject of protective or paternal legislation. Groups in the Insular ${ }^{42}$ and Chinese Exclusion ${ }^{43}$ cases were not citizens at all, and thus fair game for discriminatory state action.

Plessy v. Ferguson, ${ }^{44}$ on the other hand, compelled the segregation of a group that had been admitted to full citizenship: African-Americans. But the case was nonetheless an easy one for the Fuller Court judges and most of their contemporaries, who readily found a police-power justification for separating the races in preserving peace and good order, as well as tracking customary usages. Only Justice John Marshall Harlan dissented, on Lochner-like grounds, that compelled segregation was redistributive class legislation in favor of whites. Kansas' uncompensated taking of Mugler's brewery property was justified as a health, safety and moral measure, a prophylaxis against the "disease, pauperism and crime" traceable to the evil of alcohol. ${ }^{45}$ Hodges,${ }^{46}$ on the other hand, although it concerned white gangs violating blacks' core liberties, fit into the system of court-enforced contractual limits on federal power; once the Court decided (in the Civil Rights Cases $^{47}$ ) that blacks had no right to federal protection against private action. For protection of their rights, they must " $\operatorname{tak}[\mathrm{e}]$ their chances with other citizens in the states where they should make their homes." 48

To save space, I won't multiply Fiss's examples, but their cumulative effect is to leave us with a much more complicated picture than the social-contract system of liberty-protected-by-judicially-enforced-limitson-constituted-authority that begins his book. Instead of a rather small and limited state, making occasional darting forays into the natural social realm under the watchful eyes of courts keen to keep the state

40. Id. at 177 .

41. Id.

42. Downes v. Bidwell, 182 U.S. 244 (1901); Hawaii v. Mankichi, 190 U.S. 197 (1903); Dorr v. United States, 195 U.S. 138 (1904); Balzac v. Porto Rico, 258 U.S. 298 (1922).

43. Chae Chan Ping v. United States, 130 U.S. 581 (1889) (The Chinese Exclusion Case); Chew Heong v. United States, 112 U.S. 536 (1884); United States v. Jung Ah Lung, 124 U.S. 621 (1888); Fong Yue Ting v. United States, Wong Quan v. United States, Fong Yue Ting v. United States, 149 U.S. 698 (1893).

44. 163 U.S. 537 (1896).

45. Mugler v. Kansas, 123 U.S. 623,658 (1887).

46. Hodges v. United States, 203 U.S. 1, 18-20 (1906).

47. 109 U.S. 3 (1883).

48. Hodges, 203 U.S. at 18-20. 
within its limits, we have a rather pervasive and powerful array of state functions and corresponding actions. The state is not simply stirring a few extra artificial ingredients into an already functioning organic social sphere. Rather, it is helping to constitute the social sphere by enforcing property and contract rights, providing the basic conditions of public order underwriting the safety and continued existence of society, and repelling threats to both the appropriate operation of the social sphere and to the foundational order beneath it. Alongside the "social realm" of freely-contracting individuals, moreover, the law recognizes a special realm of persons of less than full legal capacity, subject to a much more intrusive range of paternalist and protective state action. And with respect to total outsiders, all bets are off and none of the regular limits apply, since they are strangers in the land.

This revised scheme gives us a fuller and more accurate picture of late nineteenth-century conceptions of the courts' role in enforcing the social contract. But I'd like to suggest it still seriously understates the role that law had come to be assigned in maintaining what Fiss calls the realm of the "social." In my view, the "relation of state to subject" had come, to use Fiss' own terms, to be thoroughly "organic." Notwithstanding the constitutional courts' increasingly activist and notorious enforcement of placing some limits on state powers and functions, the use of the state and law to maintain, and defend against threats to, organic social order had become increasingly frequent, intrusive, and not generally subject to much, if any, constitutional limitation.

Fiss attributes to his judges a paramount concern with promoting and protecting the proper operation of the social realm of property, exchange and free labor, in which all (sui juris) individual persons have equal claims with all others to rights, i.e., to legal/political arrangements and institutions protecting their capacity for self-realization through free exercise of their faculties consistent with like rights in others. This seems right to me as at least a partial description of the core concerns of classical liberalism. One of its central institutions is indeed a moralized political economy, the Jacksonian-Ricardian competitive economy of small producers that, if allowed to function correctly, will return to each individual a reward equal to his inputs of effort, talent, and abstinence.

Fiss also attributes to the judges a belief that in the United States, the existence and smooth operation of such a social realm was assumed as a more or less "natural" fact, what Hayek would later come to call a "spontaneous order." 49 Also, many nineteenth-century Americans talked as if this social realm was indeed the set of arrangements that uncorrupted human beings, possessed of natural reason, enlightened

49. Friedrich A. Hayek, Law, Legislation and Liberty 35-54 (1973). 
self-interest and moral sense, would choose for themselves. The main role for law and the state in this vision is to clear away historically created obstructions: to release natural man from encrustations of custom, superstition and artificial restraint - restrictions on mobility of land, labor, and capital; mercantilist wage and price controls; ecclesiastical hierarchy, aristocracy and monopoly; agrarian and sumptuary laws; and redistribution by confiscation and taxation. Once established, the system is a machine that, without undue interference, runs of itself according to the natural laws of moralized political economy - producing the individual characters that will sustain and reproduce it.

Alternatively (and probably more frequently), the social realm was described, in the conservative historicism of nineteenth-century jurists, not as a natural fact but as a complex historical achievement - in the shaping of institutions, but perhaps even more of appropriate characters. The individual character demanded for the appropriate function of the sphere of natural liberty is a complex social product, the outcome of a long, slow process of historical evolution toward a civilized society peopled with civilized individuals - of inherited traits, inherited institutions, and a thick web of supporting social arrangements and institutions. The progress of society, civilization, morals, natural religion, learning and useful arts was gradually producing the ideal individual characters to be bearers of liberal rights: nonconformist Protestant middle-class personalities, pursuers of enlightened self-interest tempered by regard for equal rights of others, and possessing strong internalized moral dispositions to self-control, thrift, discipline, and avoidance of license and vice. In the Victorian Anglo-American world (at least outside the "feudal" South), this progress toward liberal society and the liberal characters that sustained it was taken to be a largely established fact. This contrasted with Europe, where much struggle, reform and even middle-class revolution might still be needed as midwives to the birth of liberal society, and personality remained deformed under the yokes of feudalism and religious superstition (a.k.a., Roman Catholicism).

The implications of this position for the governance of evolutionarily stunted peoples were naturally various. Optimists thought that with a change of environment by means of immigration or colonial government, backward races could assimilate in a generation; racists thought them inherently incapable of ever assimilating. Most in between thought they could get there eventually, though it might take hundreds of years. Classical liberal theory was an idealized view of what the Anglo-American middle class thought it had already achieved for itself, and thought could be achieved for virtuous working- and lower-class 
people, and even some lesser breeds, with appropriate socialization from above and through their own efforts from below.

Herbert Spencer, whom Fiss identifies as a primary theorist of liberal society, ${ }^{50}$ blended the naturalistic and historical accounts into a socio-biological model, according to which the increasing division of labor and specialization of social functions had, over centuries, gradually stimulated a responsive evolution of inherited adaptive reflexes and instincts in the human mind. The happy outcome was that coercion would no longer be needed to produce the conditions of self-sustaining market society. ${ }^{51}$ J.S. Mill agreed: "Despotism is a legitimate mode of government in dealing with barbarians, provided the end be their improvement ... [ [but in civilized nations] mankind have attained the capacity of being guided to their own improvement by conviction or persuasion." 52 A conclusion one might draw from these accounts of the equilibrium of liberal society is, certainly, that once it is reached, the only job for "artificial" institutions like the state is routine servicing and maintenance of the natural organism of society, and occasional repulsion of threats to its safety or smooth functioning.

The stewards of the legal system in Victorian America often pronounced these libertarian sentiments. But by and large, they didn't act as if they believed in them. Rather, their view was that sustaining conditions of the social realm, and especially of the individual moral characters needed for its operation, couldn't allow taking people as they found them, since the natural state of persons was fallen, weak, and sinful. The sustaining conditions of social life thus depended on very particular types of socializing and "disciplining" institutions and agencies: families, sexual codes, schools, workplaces, correctional institutions, and, of course, properly functioning markets. The glue of society was, in bonds of community and authority, what sociologist Emile Durkheim called the non-contractual foundations of contract. ${ }^{53}$ The social sphere of liberty rested on a foundation of both socially produced restraints and coercively maintained order; the order of competition on spheres of social life protected from competition and arm's-length bargaining; the order

50. This identification incidentally seems to me mistaken: American classical judges and lawyers were not generally followers of Spencer or of Social Darwinism; they admired contractual liberty for political-economic and moral reasons, not evolutionary-biological ones. For a nice elaboration of this point, see Herbert Hovenkamp, The Cultural Crises of the Fuller Court, 104 Yale L.J. 2309 (1995) (reviewing Owen Fiss, Troubled Beginnings of the Modern State, 1888-1910 (1994)).

51. See generally Herbert Spencer, Social Statics (1896); Herbert Spencer, Principles of Sociology (1896).

52. John StUART Mill, ON LiberTy 10 (Elizabeth Rappaport ed., 1978).

53. Emile Durkheim, The Division of Labor in Society 206-19 (George Simpson trans., 1933). 
of equal rights on relations of hierarchical subordination. Indeed, some of these orders, like the natural authority of the employer and subordination of the employee in the workplace, were actually built into the heart of liberal order itself, not just into its foundations. And all these foundational orders turned out to require much more significant legal reinforcement, legal delegations of discretionary power, and legal coercion to make them work than classical-liberal theory generally liked to recognize, except in moments of crisis.

A nice set of illustrations comes from Sarah Barringer Gordon's recent work, an excellent and revealing book about the legal response to Mormon polygamy. ${ }^{54}$ From 1860 to 1890 , the federal government was mobilized to deploy an extraordinary arsenal of legal resources against Mormon families, churches, economic institutions, and political arrangements. In just a few years, the government disenfranchised polygamists and even those who merely advocated polygamy, repealed women's suffrage in the Utah territory, disqualified polygamists from jury duty, criminalized plural marriage and brought 2,500 prosecutions ${ }^{55}$ against polygamists, including 200 against pregnant women for "fornication." 56 The federal government's legal campaign to reform sexual behavior was "unique in American history ... far exceeding that of seventeenth-century Massachusetts" 57 It dissolved the corporation of the Mormon Church and escheated its property to the state, limiting its holdings of real property to $\$ 50,000 .^{58}$ These were, of course, massive interventions into religious, family and economic life - not to mention massive exercises of federal power with respect to arrangements typically assigned to "local" regulation. Naturally, one asks: How could people who supposed they were devoted to freedom of contract, the "voluntary principle" in religion, and the preference for localism in matters of domestic relations, do all this without the slightest hesitation? The campaign against polygamy is one of the many episodes that makes one sharply aware of the primacy to classical liberalism of its moral foundations: monogamy, the channeling of sex into marriage, the differentiation of women in their separate sphere as tamers of male passion and civilizers of male impulses, all essential prerequisites to the functioning of a society and market economy, that would render everyone his moral due. "Liberty" was an important protected interest when it served that ulti-

54. Sarah Barringer Gordon, The Mormon Question: Polygamy and Constitutional Conflict in Nineteenth Century America (2002).

55. Id. at 152-55.

56. Id. at 181 .

57. Id. at 156.

58. Id. passim. 
mate goal, but dangerous and vicious when it flowed outside its proper channels.

As Fiss's narrative of the period dramatically indicates, by the 1880s and '90s most people no longer believed in the most optimistic evolutionary fairytales of progress toward an almost completely self-sustaining economy of virtue, requiring only minimal booster shots of legal force to keep it humming along. Doubtless, people in every age perceive their social order as undergoing breakdown. At the end of the last century it really was breaking down. Corporate and labor combinations, subsidies and special tax breaks that distorted the competitive market, allowing monopolists and unions to reap rents far in excess of their rightful shares, taxation schemes and pauper relief that might give more than their due to either the idle rich or the idle poor, and debtor relief and debt repudiation all were bad for exactly the same reasons polygamy was bad. These policy measures interfered with the operations of the moral economy; they corroded the conditions of character-formation.

Why were legal-social reformers - not just the tradition-minded or rural reformers, but modernizing Progressives, as well - so obsessed with suppressing obscene literature, gambling, alcohol, prostitution and other forms of vice? Nicola Beisel has plausibly explained these obsessions as the product of middle-class parents' worries that their sons would fall off the wagon of respectability into debauchery and thus jeopardize their futures as self-controlled characters, and with them, the future of the moral economy itself. ${ }^{59}$ Mass unemployment and injuries from industrial accidents threatened the stability of the family as the moral basis of civilization by undermining the independence, founded on the wage-earning capacity, of the male head of household. ${ }^{60}$ The tremendous influx of outsiders threatened to swamp liberal society with characters who were not socialized, and perhaps never could be, into habits of industry and self-government. These outsiders included immigrants who were still under the sway of feudal habits; Catholics and socialists, habitually idle paupers; or those who were altogether excessively, inhumanly hard workers like the Chinese and Japanese; and, of course, the recently freed slaves.

The most interesting of these threats, for my purposes, are those that seemed to derive from the market system itself, to be byproducts of its routine operations. The most conspicuous among these was the tendency of free contracting and entrepreneurial liberty to beget giant busi-

59. Nicola Beisel, Imperiled InNOCENTS: ANTHONy CoMstock and Family Reproduction in Victorian AMERICA 49-75 (1997).

60. See generally John WItt, The Accidental Republic : Crippled Workingmen, Destitute Widows, and the Remaking of American Law (forthcoming 2004). 
ness combinations that put out of business the "small dealers and worthy men," as Justice Peckham called them, ${ }^{61}$ who were the sturdy mainstays of the moral economy, and therefore called for injections of legal force to restore its healthy functioning. Fiss has a brilliant chapter on antitrust, describing the Fuller Court judges' contortions to fit the enforcement of the Sherman Act, designed to "protect the market from itself,"62 into their scheme of limits on constituted authority to meddle with the natural workings of the market.

Antitrust was one of several fields in which classical judges repeatedly disagreed about whether an agreement to combine was a normal transaction within the sacred sphere of core liberty/property actions or a threat to that sphere; this threat had to be contained to protect the foundational conditions of its natural functioning. All the judges had differing views of what the "natural" conditions were. Justice Peckham, Fiss tells us, "referred to competition as though it were itself a 'rule' or a 'law.' He often spoke of the 'general law of competition,' as though the Sherman Act were nothing more or less than the transubstantiation of a law that governed anyway - natural law."63 Justice Holmes, by contrast, viewed the growth of business combinations as part of a different natural process altogether; the evolution of social organizations into collective forms and business combinations as the irresistible organic law of social life. In his remarkable dissent in the Northern Securities ${ }^{64}$ case, Holmes warned that adoption of the Peckham view, "an interpretation of the [Sherman Act] which in my opinion would make eternal the bellum omnium contra omnes and disintegrate society so far as it could into individual atoms . . . would be an attempt to reconstruct society"65 and would be not only foolish but actually unconstitutional. So even for Holmes - whose relish in upholding legislation usually only increased with his opinion of its absurdity - there were limits: Congress could not be presumed to have attempted to repeal the law of evolution. But the problem remained that, by its literal terms, the Act seemed to prohibit all contracts in restraint of trade, threatening, as Justice White put it, "all liberty of contract and all substantial right to trade, and thus causing that act to be at war with itself by annihilating the fundamental right of freedom to trade which, on the very face of the act, it was enacted to preserve ...." 66

White's eventual compromise in Standard Oil's and American

61. United States v. Trans-Missouri Freight Ass'n, 166 U.S. 290, 323 (1897).

62. Fiss, supra note 1, at 109.

63. Id. at 123.

64. N. Sec. Co. v. United States, 193 U.S. 197 (1904).

65. Id. at 411 (Holmes, J., dissenting).

66. United States v. Am. Tobacco Co., 221 U.S. 106, 180 (1911). 
Tobacco's "rule of reason," 67 as is well known, drew on Judge William Howard Taft's famous opinion in circuit in the Addyston Pipe case, ${ }^{68}$ which had said that the Sherman Act simply enacted "common law" principles on restraint of trade. This formula helped to solve the problem of reconciling "artificial" and "coercive" regulation of activity in the "natural" and "social" sphere by naturalizing the form of regulation itself. It suppressed the public-coercive element in regulation by concealing it in the folds of the "common law," viewed as a gradually unfolding outgrowth of organic custom, which, even though judges enforced it and kept revising it, was somehow not "the state," not an alien excrescence working on the social body from outside, but part of spontaneous order itself. The judges in short solved the problem by defining the social sphere as including built-in, natural-law-derived restraints on predation.

Labor combinations posed similar conceptual difficulties for theorists of freedom. It was easy for the judges to see strikes, pickets, and boycotts as interferences with owners' natural-liberty rights to run their businesses (properties) as they saw fit, which included the liberty to hire and fire whom they chose and, in the context of workers' rights, to contract individually for their labor. It was even easier for them to perceive potential coercion or violence, from the barest evidences of actual conduct - such as the mere presence of labor pickets - as severe threats to public order that could be suppressed by the police power or the inherent equitable power of the courts. But what if the means which the state legislatures chose to try to solve the public order problem were conciliation rather than repression, as by enacting anti-yellow-dog statutes or other pro-labor legislation? Classical courts for the most part rejected this solution as "class legislation" beyond the bounds of police power, and as capitulation to blackmail (though they had no difficulty accepting the very similar rationale for compelled racial segregation as a safeguard against unlawful violence). Here, too, as Fiss points out, there were dissents, such as Justice McKenna's in the Adair case, which would have justified labor legislation as contributing to industrial peace. ${ }^{69}$

But in general, confronted with threats to the public-order and moral-order foundations of the social sphere, legal authorities were disposed to respond with repression to repel the threat and restore order, even if the threats arose from the self-undermining effects of routine

67. Standard Oil Co. v. United States, 221 U.S. 1 (1911); Am. Tobacco, 221 U.S. 106.

68. United States v. Addyston Pipe \& Steel Co., 85 F. 271 (6th Cir. 1898).

69. Fiss, supra note 1, at 171 (citing Adair v. United States, 208 U.S. 161, 185-86 (1908) (McKenna, J., dissenting)). 
exercises of contractual liberty itself or if doing so might in the process severely curtail contractual liberty. In order to protect the voluntary selling of self into wage labor as the paradigmatic act of freedom, the legal system criminalized workers' refusal to do so with increasingly repressive and repressively enforced, vagrancy laws - lest idleness and pauperism corrupt the character of the unemployed. ${ }^{70}$ Courts upheld these laws despite their almost total absence of due process: police could arrest on bare suspicion, without witnesses to actual begging, while suspects were presumed guilty and rapidly dispatched to compulsory workhouse labor. The courts also saw dangers to the organic hierarchies of family order in the expansion of married women's contractual capacities and opportunities. As wives entered the wage workforce and earnings acts enabled them to control the proceeds of their labor and thus achieve some "pecuniary independence" within the household, the courts, as Reva Siegel has shown, refused to allow their new freedom to contract to affect their duties to perform domestic services. These domestic services remained personal and unwaivable obligations; the wife's earnings from third parties still came under her husband's control unless she expressly labored on her "sole and separate account."71 When young women sold their sexual services to get higher wages and more spending money than they could earn as seamstresses or shop-girls, the legal system (which in earlier decades had generally resigned itself to considering prostitution as an inevitable evil having the beneficial side-effects of deflecting male sexual urges away from respectable and onto fallen women) began to resort to more draconian regulation to eradicate this form of exchange. ${ }^{72}$

As with free contract, so with free speech; Mark Graber has convincingly argued that to "conservative libertarians" of the late nineteenth century, free speech was conceptually on a par with contractual liberty as a core liberty to be protected against the state - that is, it was an integral piece of the social sphere. But as Graber concedes, and Fiss demonstrates in his book, if a speaker's words seemed to have any tendency at all, however remote or improbable, to threaten public order, the

70. See William Cohen, At Freedom's Edge: Black Mobility and the Southern White Quest FOR RACIAL CONTROL, 1861-1915 (1991) (discussing the use of vagrancy laws to prevent migration of black labor, to assist in compulsory contract enforcement, assert control over defiant or rebellious blacks, and to supply pool through the convict labor system for an involuntary labor force); Amy Stanley, From Bondage ro Contract 103-33 (1998) (describing the arrests of thousands of "tramps" in Northern cities per year, in sweeps of 20 to 500 per day).

71. Reva Siegel, Home as Work: The First Women's Rights Claims Concerning Wives' Household Labor, 1850-1880, 103 Y ALE L.J. 1073, 1170-89 (1994).

72. See Ruth Rosen, The Lost Sisterhood: Prostitution in America, 1900-1918, 1-37 (1982). 
speech could be suppressed. ${ }^{73}$ A nice, dramatic illustration comes just after Fiss's period in Fox $v$. Washington, ${ }^{74}$ in which the Supreme Court upheld the criminal conviction of an author for writing an article called "The Nude and the Prudes," which praised nudism, protested the arrest of nudists, and called for a boycott of the "prudes" who had instigated the arrests. ${ }^{75}$ The Court construed this article as a punishable incitement to breach of the indecent-exposure statutes.

In the South especially, as Peter Bardaglio and Laura Edwards have shown, law and the state took over the paternalistic role of the antebellum patriarchal household as the primary regulator of society's organic relations after slavery disappeared. The legal system regulated not just "the family," but the whole social-sexual code. This was accomplished through the protection of female virtue, most notoriously through savagely punitive legal and extra-legal enforcement of rape and sexual assault laws against black men, and also through refusal to protect women (of any race) who were perceived to flaunt their sexuality against white men. These means were accompanied by a tightening of anti-incest laws and a strenuous policy of compelling into marriage former slaves who had previously not been allowed to marry. Needless to say, the legal and extra-legal enforcement of the sexual code of vagrancy laws was most likely to be targeted at blacks who were actually proving their moral worth in the economic order by acquiring property and moving up the ladder. ${ }^{76}$ Preservation of racial status order, rationalized as preservation of sexual and public order, easily trumped contractual liberalism in this setting.

Faced with mounting evidence that the operations of the free-contract economy themselves might be producing disturbances to its foundational order, legal authorities in this period generally resorted to denial and scapegoating - usually by attributing the disturbance to defects in character introduced by corrupt, impure, or foreign influences. Fiss quotes at length a remarkable speech by Justice Brewer, who admits that free markets produce great inequalities - as is only natural and just, because men differ greatly in their capacities for "self-denial and saving" and "business tact and sagacity."77 Inequality, in turn, produces

73. Mark A. Graber, Transforming Free Speech: The Ambiguous Legacy of Civil LIBERTARIANISM 17-49 (1991).

74. Fox v. Washington, 236 U.S. 273 (1915).

75. Id.

76. See generally Peter Bardaglio, Reconstructing the Household: Families, Sex and the Law in the Nineteenth Century South (1995); Laura Edwards, Gendered Strife and Confusion: The Political Culture of Reconstruction (1997).

77. FISS, supra note 1, at 54 (quoting David Brewer, The Nation's Safeguard, ProcedurEs of the New York State Bar Association 38 (1893)). 
envy and the desire to redistribute wealth. But what inflames envious desire into lawless violence is foreign influence: "the black flag of anarchism, flaunting destruction to property, and, therefore [the] relapse of society to barbarism" and "the red flag of socialism . . .."78 In interesting recent work, Matthew Lindsay has traced the origins of the Contract Labor Act of 1885, which was aimed at prohibiting employers from importing cheap foreign labor that would undercut domestic wage rates. ${ }^{79}$ Its backers were alarmed at the depression of wages below levels that would enable men to support a family and be independent republican citizens. But rather than admit that market outcomes might not support the moral economy of virtue, they initially blamed ruinous wage competition on the socially acquired, then later the inherent racial defects of Southern European "pauper laborers" - whose peculiar degeneracy was not refusal to work, but willingness to work for peanuts, as men not accustomed to Anglo-Saxon liberty and thus too degraded to insist on the wages that would maintain them in it. ${ }^{80}$

Classical liberals, in short, tended to diagnose the basic problem as defective human inputs into the moral economy, rather than the operations of the economy itself. If the human material was the problem, the cure must lie in some combination of measures to reshape or repair deficient characters, or if they should prove obdurately refractory, to exclude or expel them. This brings us into the vast territories first mapped by historians of Victorian and Progressive moral and social-legal reform ${ }^{81}$ and since occupied and colonized by Foucault and his successors' studies of "disciplines" and "govermentality" 2 - that is, of the elaborate

78. Id. at 56 (quoting Brewer, supra note 77, at 47).

79. Matthew Lindsay, "Draw the Lines of Entrance Tight and True": Dependency, Race and the Political Economy of Immigration Law in the Gllded Age [unpublished manuscript; copy on file with author].

80. Id. See also Paul T. Ringenbach, Tramps and Reformers, 1873-1916: The Discovery of UNEMPLOYMENT IN NEW YORK 24 (1973). In a survey of New York charities personnel in 1885,16 percent attributed the "tramp" problem to unemployment; 70 percent said it resulted from personal deficiencies, "laziness, war drink, dime novels, tobacco, discontent, shiftlessness, vice, love of roving, heredity, socialistic ideas, the Chinese, [or] the devil." Id. (Thanks to Olivia Choe for this reference.)

81. For a small sample of some of the best work from a large field, see PAUL S. BoYer, Urban Masses and Moral Order in America, 1820-1920 (1978); Richard F. Hamm, Shaping the 18th Amendment: Temperance Reform, Legal Culture, and the Polity, 1880-1920 (1995); Alan Hunt, Governing Morals: A Social History of Morals Regulation (1999); Mary E. Odem, Delinquent Daughters: Protecting and Policing Adolescent Female Sexuality in the United States, 1885-1920 (1995); David J. Pivar, Purity CRusade: Sexual MORAlTty AND SOCial CONTROL, 1868-1900 (1973); Mariana Valverde, The Age of Light, Soap and Water: Social Purtty and Philanthropy in Canada, 1885-1925 (1991).

82. See, e.g., Michel Foucault, 3 The History of Sexuality: The Care of the Self (1986); Power/Knowledge: Selected Interviews and Other Writings, 1972-1977 (Colin Gordon ed., 1980); Jonathan Simon, Poor Discipline: Parole and the Social Control of 
and extensive array of social and state "technologies" deployed to form and "normalize" the individual subjects and citizens who were to be the bearers of liberal rights and obligations. In earlier periods, reform entrepreneurs had mostly been content to rely on the spontaneous order of voluntary associations (churches, Bible societies, temperance societies, and the like) - with the important exceptions of the pioneering big disciplinary institutions of compulsory public schools, prisons, asylums, and workhouses, which were already up and running by the 1830 s and '40s. ${ }^{83}$ Moral reformers had also begun, by the mid-nineteenth century, to turn to the state to regulate the most worrisome and conspicuous forms of vice, such as lotteries, gambling, and alcohol.

In Fiss's period, they turned to law and the state for new sources of funding, personnel, legitimacy, and coercive enforcement authority. Sometimes these took the form of new or more punitive criminal laws, sometimes of administrative regimes with rehabilitative mandates, sometimes of new state agencies, and, perhaps most imaginatively of all, delegations of state authority to enter, search, investigate, seize, incarcerate, and fine to professional groups or citizens' groups such as Comstock's Society for the Suppression of Vice, the Child Protection Societies, Commissions on the Social Evil, and the Anti-Saloon Leagues.

I could not even begin to try to summarize all these legal initiatives here; but let me briefly group them into types and give a few examples of each: (1) Measures to shore up and enhance the capacity of traditional socializing institutions mostly took the form of protecting the sexual division of labor and gender roles and the monopoly of procreationwithin-marriage as the legitimate outlet for sexual urges, such as new legislation outlawing common-law marriage, abortion, selling or distributing information about contraception; banning and seizure of obscene materials; new crackdowns on prostitution; the restriction of professional and other job opportunities for women to prevent them from competing with men for the role of household provider and to safeguard their capacities as wives and mothers; (2) Codes and institutions to correct the characters of deviants, especially children: new reformatories for juvenile delinquents and sexually wayward girls; removal of children from working-class homes with bad values; houses of rescue for fallen women; intensive supervision of relief recipients; (3) Outright repression or exclusion of groups presenting special social dangers: mass

the Underclass, 1890-1990 (1993); Nikolas Rose, Powers of Freedom: Reframing Polmical Thought (1999).

83. On these institutions, see David Rothman, Discovery of the Asylum; Social Order AND Disorder IN tHE New Republic (1971). 
deployment of injunctions (around 2,200 issued between 1880 and $1920)^{84}$ to suppress labor actions; concerted and largely successful campaigns to "purify the electorate" by disenfranchising whole categories of voters - including (in the South) virtually all African-Americans, and (in the North) immigrants, the propertyless, low-income persons unable to pay a poll tax, those unable to read English, mobile populations disabled by residency tests, "paupers" (which included anyone who had received poor or work relief, and workers out on strike), and those unable to meet picky detailed registration requirements; ${ }^{85}$ new controls on the unemployed and "sturdy beggars" through stiffer vagrancy laws and (in the South) of black farmers unwilling to work for their former masters through criminalizing contract-breaking; ${ }^{86}$ cascades of new laws criminalizing speech, organizations and association of politically threatening groups like "anarchists" or "syndicalists"; 87 and, of course, exclusion of a whole host of undesirables, from low-wage contract labor, to radicals, anarchists, and the Chinese. ${ }^{88}$

I hasten to emphasize what the best work on these reform movements makes clear: that they emerged from a wide variety of interests and ideological positions and were by no means all directed to subordinating and controlling the poor and marginal, or to preserving traditional privileges and hierarchies. Though some of these initiatives had precisely those aims, or after more promising beginnings came to be captured by factions with those aims, other movements aspired earnestly and even radically to improve the conditions of the downtrodden and to curtail the powers and reform the characters of the wealthy and mighty. The point is just that the array of legal tools and strategies the reform movements - often spearheaded and staffed by lawyers, by the way were willing to deploy to address rampant social diseases showed very little disposition to prevent law and the state from invading contractarian boundaries on interference with the self-sustaining and self-reproducing social sphere of natural liberty.

Indeed, the judges guarding the boundaries reviewed and approved the vast majority of these initiatives. Sometimes the reason they gave

84. This estimate comes from William Forbath, LAW and the Shaping of the American LABOR Movement 193 (1991). The bonanza decade for injunctions was the 1920s: 2,130, by Forbath's estimate. Id.

85. Alexander Keyssar, The Right to Vote 77-171 (2000). The extension of voting rights to women was a rare countertendency.

86. COHEN, supra note 70.

87. For an inventory of laws suppressing speech and dissent, see generally ROBERT J. Goldstein, Political Repression in Modern America: From 1870 to the Present (1978).

88. For the exclusionary measures, see the classic work of John Higham, STRANGers IN tHE LAND: PatTerns OF AMERICAN NATIVISM, 1860-1925 (1966), and the recent synthesis of Rogers Smith, Civic Ideals: Conflicting Visions of Citizenship in U.S. History 347-469 (1997). 
was that the measure fell within the scope of the police power, which usually turned out, unless it infringed directly on the negotiation of the wage bargain, to be pretty broad. The courts approved what might appear to be blatantly anti-competitive rent-seeking arrangements such as occupational licensing, the exclusion of women from professions and occupations, and the stringent regulation of dairy-product substitutes. They were especially indulgent if the legislative rationale was protection of morals, and disposed in such cases to accept the flimsiest and most speculative claims of the risks of social harm posed by the regulated conduct. Sometimes the reason the courts gave was, as in Debs (the Pullman Strike Case) ${ }^{89}$ or Reynolds (the Mormon Polygamy Case), ${ }^{90}$ that the measure was needed to protect the very foundations of social order itself, such as the family or civil peace or political stability, which were prior and superior even to maintenance of the moral economy of the social sphere. And very frequently, the ground was simply the common device that the legal system uses to avoid confronting uncomfortable illiberal hierarchies or exercises of discretionary authority: that the claimed anti-liberal practice, like the state's failure to protect the contracting rights of Southern blacks or the rights of women to be free of domestic violence, or its arbitrary exclusion of aliens or dissenters, was simply in somebody's else's jurisdiction.

Does this mean I think Fiss has just invented this libertarian vision of judicially enforced limits on constituted authority - in the same fashion as legal Progressives trumped up the charge (of which Fiss is inclined to acquit them) that the classical judges were mere lackeys of big business? Of course not; the cases are there, and so is a towering heap of briefs and speeches and articles and editorials presenting and justifying this vision. The classical judges' belief in the quasi-natural social sphere or moral economy was entirely sincere - even if it may seem to modern libertarian eyes radically at odds with the entire panoply of state action of the period, which now seems more notable for its impressive array of novel controlling, disciplining, coercing, punishing, and excluding state strategies than it does for restraining heavy-handed state interventions into the social sphere. The tendency of libertarian legal and political-economic theory to ignore or repress awareness of the state and of state-supported coercive preconditions to the functioning of free contracts and free markets has been a favorite theme of critics from Marx, Proudhon, and Hobhouse, to legal Progressives like Robert Hale. ${ }^{91}$ But this isn't just a story about self-deception, myopia, or bad

89. In re Debs, 158 U.S. 564 (1895).

90. Reynolds v. United States, 98 U.S. 145 (1879).

91. See, e.g., Karl Marx, On the Jewish Question, in The Marx-Engels Reader 26 (Robert 
faith: As Fiss points out, social-contract ideology really was in actual practice a powerful tool for structuring much of the judges' decisionmaking - even if they were prone to deviating from or betraying it in the crunch. And, as he also points out, contractual-liberty ideology had some significant relative-autonomy-feedback effects (my hideous phrasing, not his), moments when classical-liberal judges or lawyers used libertarian arguments against illiberal state initiatives that powerful interests wanted. Fiss's book has many such examples: the vigorous dissenters in the Insular Cases; Justice Harlan's dissent in Plessy; the Northern Securities majority, maybe the majorities who defended the interstate liquor trade against state prohibitionists, and the arguments of the consummate classical-liberal James Coolidge Carter ${ }^{92}$ - who wrote whole books naturalizing private common-law-structured society as the slow organic growth of custom, a delicate ecology to which ill-conceived popular legislation could cause inestimable damage, but who also argued for the government in favor of the income tax and against it in the Chinese Exclusion Cases. ${ }^{93}$

But even the most aggressive libertarians of the time took for granted the legitimacy of a wide range of legal coercions. Christopher Tiedeman's famous Treatise on the Limitations of Police Power in the United States, ${ }^{94}$ appearing on the eve of Fiss's period, much cited by lawyers and judges during it, and later much reviled by Progressive critics for its "laissez-faire" views, is a rich storehouse of examples - both of the potentially expansive ripple effects of legal-libertarian ideology and of its limits. Tiedeman attacks many forms of regulation that classical-liberal courts had generally validated - economic regulation of interest charges (usury laws), ${ }^{95}$ price and terms of service of public accommodations, ${ }^{96}$ and oleomargarine. ${ }^{97} \mathrm{He}$ disparages prohibition of mere consumption of drugs and alcohol, ${ }^{98}$ the regulation of private enjoyment of vices such as gambling and fornication (although he condoned the regulation of vices such as gambling houses, brothels, and the

C. Tucker ed., 2d. ed. 1978); Pierre-Joseph Proudhon, General Idea of the Revolution in THE Nineteenth Century 294 (J.B. Robertson trans., 1923) (1851); Robert L. Hale, Bargaining, Duress and Economic Liberty, 43 Colum. L. Rev. 603 (1943).

92. Fiss, supra note 1 , at $235,255-56,365-66,133-34,306-08$.

93. On Carter's relatively progressive liberalism, see Lewis A. Grossman, James Coolidge Carter and Mugwump Jurisprudence, 20 LAw \& Hist. Rev. 577 (2002).

94. Christopher Tiedeman, Treatise on the Limitations of Police Power in the UNITED STATES (1886).

95. Id. at 238-41.

96. Id. at 233-38.

97. Id. at 295-97.

98. Id. at 148-53, 301-09. 
liquor trade, even if outright prohibition would probably be futile), ${ }^{99}$ laws criminalizing the status of being a "habitual offender," 100 and many others. Tiedeman thinks laws preventing women from entering the professions ${ }^{101}$ and marriages between people of different races are the result of sheer prejudice, the latter "an uncontrollable prejudice against the black man, and a desire to maintain the inequality of his present social condition." $102 \mathrm{He}$ thinks the process (though not the substance) of vagrancy laws - arrest on suspicion, summary process, and reversal of the burden of proof - to be of dubious validity. ${ }^{103}$ For his time, this is a courageous and appealing libertarian tract, but one that also, by its long lists of conventionally accepted police-power offenses, shows how ill the "laissez-faire" label fits the law of this period. Tiedeman's chapter on free speech and free press is only four and one-half pages long, and largely defines the rights as freedom from prior restraints; ${ }^{104}$ "anarchists and nihilists" may be arrested and their publications seized for producing "inflammatory appeals to the passion of discontents," 105 and blasphemers against the Christian religion may be punished for injuring the public by diminishing respect for a religion that sustains the moral basis of the state. ${ }^{106}$ And given the severity of the "racial" threat from the abnormally hardworking and morally depraved Chinese, legislatures might reasonably think their exclusion was essential to protect the country from being overrun by the "almond-eyed Asiatic."107 My favorite passage of the treatise, which reveals his characteristic method of balancing liberty and social-order preservation, is his carefully nuanced discussion of the legal regulation of cross-dressing, "the prohibition of the appearance in public of men in women's garb, and vice versa":

The use of such dress could serve no useful purpose, and tends to public immorality and the perpetration of frauds. Its prohibition is, therefore, probably constitutional. But it does not follow that a law,

99. Id. at 289-311.

100. Id. at $124-31$.

101. Id. at 201-03.

102. Id. at 536.

103. Id. at 116-22. In justifying the substance of laws punishing vagrancy, the status of being without "visible means of support," Tiedeman had to wage an uphill battle against his honest libertarian conviction that there could be no social harm in idleness or refusing to work per se. "A man has a legal right to live a life of absolute idleness, if he chooses, provided he does not, in so living, violate some clear and well defined duty to the State." Id. at 118. The "gist of the offense," he reasoned, was "threatening to become a public burden." Id. The best evidence one could hope to find of the general acceptance of vagrancy laws is that a strongly committed libertarian like Tiedeman was willing to find social harm, justifying preventive action, in such a speculative unrealized "threat."

104. Id. at 189-93.

105. Id. at 193.

106. Id. at 167.

107. Id. at 145 . 
which prohibited the use by men of a specific article of women's dress, or to women the use of particular piece of men's clothing, would be constitutional. The prohibition must be confined to those cases, in which immorality or the practice of deception is facilitated, viz., where one sex appears altogether in the usual attire of the other sex. ${ }^{108}$

For the classical liberals, then, the order of liberty in the social sphere was deeply, even if not always openly or explicitly, parasitic on foundations of organic order, the basic conditions of social peace and political stability and of the institutions and ethical dispositions counted on to produce the individual characters needed to make the order of liberty function. These conditions, in turn, were deeply reliant on structuring and coercive law - although theorists such as Spencer liked to believe that the need for state coercion was vanishing as liberal behavior became habit and instinct, and legal historicists liked to believe that the essential legal component, private common law, was itself an evolving organic order rather than an artificial excrescence like state legislation and administration. When this foundational order came under siege even and perhaps especially when the source of dangerous pollutions was the sphere of liberty itself (new opportunities for women and blacks to be potentially equal rights-bearers in the economy, new inequalities and mass unemployment resulting from the industrial system, new national labor organizations and their mass actions to match industries national in scope, new weird religions and political heresies emerging from the pluralist marketplaces of free speech and the voluntary system, and new race threats from the mobility of free labor) - massive new doses of restructuring and coercive law were pumped into the system to repel the threats and restore and refashion the conditions of order. The conditions, made visible, were often strikingly illiberal, thus setting up occasions for battles between the apostles of liberal order and defenders of its illiberal foundations. In retrospect, one of the worst things the courts of this age did was to ratify so repeatedly and uncritically the most illiberal of those acts.

Ironically, however, as Fiss's consistently penetrating and lucid history - the history that any modern reader seeking to understand the law of this period should start with - makes clear, the Fuller Court made itself more conspicuous, controversial, and politically vulnerable in its preferred self-conception as a defender of the order of liberty than as a legitimator of the authoritarian extravagances of its time. In order to prevent the government from breaching the social contract through overreaching regulation and redistribution, the Court itself assumed the role 
of "Super Regulator," making itself the supreme arbiter not only of the constitutionality of federal and state legislation and the boundaries of federalism, but also the ultimate supervisor, by virtue of having constitutionalized the right to "fair rates of return on investment" as "property," of the rate-making decisions of every state railroad and public utility commission; ${ }^{109}$ the chief government agency, through application of the "rule of reason," for determining the scope and purpose of the antitrust laws; ${ }^{110}$ the supreme interpreter, through its exposition of general federal common law in the diversity jurisdiction, of much state tort law; ${ }^{111}$ and the ultimate governance authority, through exercise of its equity powers, over interstate labor disputes ${ }^{112}$ and bankrupt interstate railroads. ${ }^{113}$ In many of these roles, maybe especially that of supervising rate regulation, the justices were conspicuously incompetent, but even the most expert unelected body can't indefinitely withstand the howling whirlwinds it is bound to raise by making itself the supreme magistrate on so many matters of huge public controversy. So Chief Justice Warren's Court found, and so, in time, will Chief Justice Rehnquist's.

Some concluding afterthoughts. The constitution of liberal order in the "classical" period of American law is not only of historical interest. Many modern conservative politicians, public intellectuals, and lawyers now look back specifically to that period with admiring eyes, as a model for the regime of legal-economic and legal-social order they hope to revive. The two main wings of the New Right, economic-libertarians and cultural-conservatives, for obvious reasons look to different facets of classical order. Free-market libertarians admire the "Lochner era" for what Fiss calls its social-contract constitutionalism, its judicial enforcement of restraints on government regulation of economic bargaining and on progressive redistribution of income. Their program is to dismantle the regulatory-welfare programs and bureaucracies of the Progressive, New Deal, and Great Society governments, and to confine the state's role to the protection of property, the enforcement of contracts (with only very narrow defenses) and the supply of a short list of public goods, notably defense. Other New Right intellectuals admire the authoritarian social control of that period, by both state and civil society, of immorality and deviant behavior. They want to undo the cultural and sexual revolutions of the 1960s: the liberalization of divorce; the Warren Court

109. Fiss, supra note 1 , at $185-221$.

110. Id. at 148-54.

111. See generally PURCELL, supra note 2.

112. See generally ForbatH, supra note 84 .

113. See David Skeel, Debt's Dominion: A History of Bankruptcy law in America 4870 (2001). 
decisions protecting obscenity as free speech and abortion as privacy; the misguidedly soft-hearted and weak-minded indulgence of the poor with welfare entitlements, minorities with antidiscrimination and affirmative-action laws, and criminals and persons in custody with overscrupulous procedural protections.

The two wings' programs overlap in some respect: both are hostile to welfare (economic conservatives because it distorts incentives to work and redistributes wealth, social conservatives because it corrupts morals and leads to idleness and promiscuity) and to the "liberal elites" they believe have dominated universities, the media, and most governments (economic conservatives because liberals oppose unregulated capitalism, social conservatives because liberals pollute the culture with libertine and secular-humanist values). But these are really very different parties, representing constituencies from very different social and regional backgrounds; their major programs are incompatible with one another, as economic conservatives and libertarians resist the intrusion of the heavy hand of authoritarian law into individual free choice in morals and religion as well as in markets. Social conservatives see a crisis of immorality, but the hero of market society is, after all, the creative destroyer of tradition, the amoral rational-maximizing entrepreneur.

Notwithstanding these apparently irreconcilable differences, the two wings of the New Right are often able to ally effectively in political coalitions. What enables them to do so is, of course, largely that they jointly seek political power, don't care all that much about the other wing's main issues, and battle common enemies on the left. But their solidarity is also given ideological comfort - and this is the point I want to stress here - by shared traditionalist nostalgia for a past order that seems to synthesize the conflicting elements, freedom of contract ideology and social authoritarianism, in their unstable alliance of convenience. Prime Minister Margaret Thatcher nicely evoked this harmonious past when she described the aim of her radically new form of "conservatism" as the restoration of "Victorian values."114

In the classical era, judges and lawyers perceived no contradiction in their support for mostly unregulated free bargaining in the economic

114. The English cultural historian Stefan Collini has tartly remarked, "[T]he whole ideological construction of 'Victorian values' was formed in reaction to some equally hypostasized notion of the 'permissive society' of the 1960s and 1970s. . . [A] crucial element in the emotional dynamic of this reaction was the sense that people - other people, of course might be getting things they didn't 'deserve', whether it was money or sex. Since it seems pretty clear that in Britain allusions to 'Victorian values' have actually been refracted through memories of lower-middle-class childhoods between the wars, what they essentially express is a meanminded petty-bourgeois ressentiment that anyone - anyone else, of course - might get something for nothing." Stefan Collini, Victorian Values: From the Clapham Sect to the Clapham Omnibus, in English Pasts: Essays IN History and Culture 107 (1999). 
sphere and for authoritarian paternalism in the social sphere. In part, they achieved this happy complacency through compartmentalization. In a perceptive and illuminating essay on classical morals regulation, Herbert Hovenkamp has pointed out that nineteenth-century American legal theory followed social theory in conceptualizing economy and morality as parallel but separate spheres, each to be understood by distinct sciences and subject to distinct modes of regulation. ${ }^{115}$ The prolific and popular text writer Francis Wayland, for example, wrote treatises on both economic and moral science. ${ }^{116}$ As a moralist, Wayland treated men as fallen and sinful, in need of strong community and legal sanctions to restrain their selfish impulses. As an economist, Wayland took men as he found them, with whatever tastes and preferences they might happen to have, and theorized that markets would work best if such individuals were allowed to freely pursue their self-interest, this side of force and fraud. ${ }^{17}$ Fiss shows his classical judges engaging in similar forms of compartmentalization through the use of categorical reasoning. If they analyzed a case as involving the proper scope of the police power to regulate economic liberty, they insisted that legislatures show a strong health-safety-morals rationale for regulation, by means narrowly tailored to achieve the legitimate end. If the rationale on offer were protection of morals, however, that switched the judges onto another track of reasoning, where they were inclined to credit the thinnest and most speculative arguments of social danger. If the category of the regulated changed if they were dependents, such as women or children, or constitutional outsiders, such as immigrants - the mode of reasoning about them changed as well.

Hovenkamp's compartmentalization thesis gets us part of the way toward understanding how the classics theorized their bifurcated approach to state regulation of private conduct. ${ }^{18}$ Even more important, I've been suggesting, was that the classics assumed that the economic and moral-social spheres generally existed in relations of harmonious interdependence. Men with properly socialized and governed moral characters would, in their economic dealings, want the right things and behave the right ways. The market would in turn reinforce and

115. Herbert Hovenkamp, Law and Morals in Classical Legal Thought, 82 Iowa L. Rev. 1427 (1997).

116. Francis Wayland, The Elements of Political Economy (1856); Francis Wayland, The Elements of Moral SCIEnCE (1852).

117. Hovenkamp, supra note 115 , at 1453-58.

118. Again, as I have to keep emphasizing, it was never all that bifurcated. The classical legal system was not even close to a laissez-faire night-watchman state, even though many of its ideological spokesmen liked to claim it was: it approved a very large range of legal regulations of economic conduct, both traditional regulations and the many novel types that were proliferating in late nineteenth-century state legislatures. 
reproduce moral character, because economic success would reward good (thrifty, hard-working, self-denying, far-seeing, honest, talented) actors, and failure would punish bad (idle, shiftless, spendthrift, dishonest) ones.

The great problem for classical law, as for political economy and moral science, was that by the late nineteenth century both the strategy of compartmentalization and the assumption of harmonious interaction of the two spheres were rapidly unraveling. Bad moral characters were infesting market relations; economic behavior, in turn, was badly messing up the formation of moral character. The economy was producing mass unemployment and injury, destroying the moral authority of male heads of household, attracting hordes of immigrants with alien values, commercializing vice, producing the twin European pathologies of an unruly urban proletariat and a decadent and idle luxury-loving upper class, generating huge and powerful combinations of capital and counter-combinations of organized labor, and undermining both the foundations in public order and consensual morality and the approximate equalities in wealth (among white males) that Americans had always understood to be the prerequisite to an independent republican citizenry.

The responses of the state and law to restore order and morals likewise transgressed the boundaries between spheres. To regulate order and morals was to regulate the economy and individual bargaining, bigtime. The state destroyed liquor businesses and seized the property of booksellers. When the courts would not allow the state to palliate the losers in the economic struggle with redistributive, compensatory or social-insurance policies or laws enabling labor to improve its bargaining advantage or share some managerial authority with capital, the state's only option to contain the political consequences was more repression. It sent troops to break up combinations of workers. It arrested the unemployed en masse for "choosing" to be out of work. It criminalized labor agitation and advocacy of radical alternatives. The courts, which were supposed to keep the regulatory state within its constitutional limits, remade themselves into powerful regulatory agencies playing a large, and very controversial, role in administering the economy - administering the industrial accident compensation system, repeatedly intervening in labor-capital conflicts, supervising the national network of railroads in receivership, reviewing public-utility rate regulation, and, of course, striking down some legislation with much popular support.

In short, there is no harmonious synthesis of economic laissez-faire and moral authority to be found in the America of 1900 and its legal 
order. Economic liberty was dissolving the bonds of authority and proving harmful to order and morals, and the efforts to restore order and morals proving harmful to liberty. The chief practical lesson that modern conservatives can learn from their classical counterparts is a cynical one: The ability to keep at bay the awareness that the economic and social spheres may be undermining rather than reinforcing one another by finding scapegoats. The classics, as we've seen, did often try to blame their problems on impurities in the social sphere alone: corrupt and alien foreign elements (Catholics, Chinese, Southern European lowwage labor, communist radicals, etc.) or on blacks and the idle poor. If those were the sources of social problems, they could be addressed by exclusion, repression, and above all, re-socialization. The current revival of Victorian moral economy, by neo-conservatives such as Charles Murray, Gertrude Himmelfarb, Lawrence Mead, and William Bennett, ${ }^{119}$ also aims to use legal-economic-institutional arrangements to promote good and suppress bad values in the poor (though Murray is more prone than the other three to speak of the poor as victims of bad incentives, or bad genes, than of corrupted character). Thus welfare (rewarding idleness) and affirmative action (class legislation rewarding special-interest rent-seeking rather than talent and industry) are especially bad social policies.

But the Victorian social and moral critiques were generally more comprehensive than their modern counterparts: They saw bad values and disorder everywhere, not just among marginals and the lower orders. Their critiques were as much directed upward as downward - to monopoly, concentrated wealth, business predation, subsidies and tax breaks for corporations, and to the conspicuous consumption and love of luxury of the rich. Modern conservative moralists write as if the habits they deplore of self-indulgent consumerism and sexual self-expression were peculiarly the vices of the poor and of a libertine subset of the upper classes, "liberal elites," rather than of the great mass of ordinary people in modern society. ${ }^{120}$

119. See, e.g., William J. Bennett, The Broken Hearth: Reversing the Moral Collapse of the American Family (2001); Gertrude Himmelfarb, The Demoralization of Society: From Victorian Virtues to Modern Values (1995); Lawrence Mead, Beyond Entitlement: The Social Obligations of Citizenship (1986); Charles Murray, Losing Ground: American Social Policy, 1950-1980 (1984).

120. An exception is Robert Bork, whose most recent work declares that the whole society is corrupt, immoral and decadent, full of "an increasing number of alienated, restless individuals, individuals without strong ties to others, except in the pursuit of ever more degraded distractions and sensations." ROBERT BORK, SLOUChING TOWARDS GOMORRAH 63 (1996). Bork argues that this condition is the logical culmination that "liberalism" - meaning the doctrines of liberty and equality in the Enlightenment, Declaration of Independence, and Mill's On Liberty - "has been moving towards for better than two centuries." Id. So far, Bork sounds like a genuine traditionalist 
Classical-legal constitutionalism, as Fiss's book makes clear, was a far more sophisticated, coherent, plausible and even-handed jurisprudence than the Progressives - who pictured it as a mixture of simpleminded economic theory, nostalgia for a pre-corporate individualistic past, and apologia for corporate business interests of the present - ever gave it credit for. But as a social experiment, the classical legal system was a huge practical failure, on its own terms as well as in historical retrospect. It promised to deliver the optimal mix of liberty, morality, and order. Instead, it was either helpless before, or itself helped to produce, higher levels of coercive repression, immorality, and disorder. The decisions of its highest court mostly deserve their reputation as a gallery of illiberal horrors. The vogue in our own age for the revival of the classical system can only arise from an astonishing misapprehension of its actual consequences. And the program to return to the legal-social status quo ante of the $1890 \mathrm{~s}$ - a society riven by violent class conflict; mass unemployment, industrial injury and poverty-stricken old age, unspeakable levels of urban and rural squalor, corporate domination of politics and systemic racial oppression - is a truly nightmarish prospect to anyone who knows anything at all about it.

conservative, a principled antagonist of modernity. But then he resorts to scapegoating, naming the chief cause of decline as a barbarian class of liberal-intellectuals who hate America and the Western tradition. (Given that Bork himself has just thoroughly trashed both modern America and its foundational liberal traditions, this is pretty rich.) Bork also remains an enthusiast for freemarket capitalism, not acknowledging that the economic dynamism he celebrates might have had something to do with the dissolution of traditional social ties, hierarchies, shared religious convictions and authorities he deplores. 